IUS ET SCIENTIA (ISSN: 2444-8478) 2017, Vol. 3, nº 2, pp. 1-13

Vicky Tzatzaki: HUMAN DIGNITY AS A COMMON ELEMENT IN INTERNATIONAL BIOLAW AND THE RIGHT TO WATER

FECHA DE ENVÍO DE ORIGINAL: 14.11.2017 FECHA DE ACEPTACIÓN: 12.12.2017

DOI: http://dx.doi.org/10.12795/IETSCIENTIA.2017.i02.02

\title{
HUMAN DIGNITY AS A COMMON ELEMENT IN INTERNATIONAL BIOLAW AND THE RIGHT TO WATER
}

\author{
Vicky Tzatzaki, $\mathrm{PhD}$ \\ Legal Advisor \\ Special Secretariat for Water \\ Hellenic Ministry of Environment and Energy
}

Keywords: human dignity, biolaw, right to water, bioethics, human rights

Abstract. Human dignity has been a core notion in many regimes of international law, such as human rights and international humanitarian law. Respect for human dignity derives from the fundamental right to life. The right to life, considered as a peremptory rule of international law, provides human dignity with a more sophisticated status in legal terms. In other words, human dignity is no more a term with moral and ethical connotations but stemming from the right to life, it attains a legal and political dimension, evolving into a principle to be respected and protected.

The present paper is divided in two parts: the first part examines human dignity in international biolaw and in the second it is traced in the right to water. Specifically, it is argued that in the regime of international biolaw, human dignity constitutes a core concept and it comes into focus primarily as an integral qualitative element; in the right to water, the international community has recognized that respect, protect and fulfill the individuals' right to water equals to respect for human dignity. Human dignity is reaffirmed in the UNESCO Universal Declaration on Bioethics and Human Rights, being a core element of any bioethical debate, as well as in General Comment No. 15, according to which adequacy, availability, accessibility and quality of water include human dignity as a sine qua non component. However, since respect for human dignity is not yet a principle or obligation but a mere appeal for the establishment of concrete regulatory frameworks for biolaw and the right to water, it should be combined with the erga omnes obligation for the protection of the right to life, in order to solve practical and theoretical dilemmas on a global and national level.

Introductory remarks

The definition and context of human dignity has become an important part of the international vocabulary of human rights. ${ }^{1}$ The concept of dignity forms a network of interconnected ideas related to worth and value within legal and ethical discourse.

\footnotetext{
${ }^{1}$ Jackson V., Constitutional Dialogue and Human Dignity: States and transnational constitutional discourse, 65 Montana Law Review 2004, pp. 15-40, at p. 15. See also Rao N., Three concepts of dignity in constitutional law, 86 Notre Dame Law Review 2011, p. 813-272.
} 
It is a rich and meaningful concept, which matters because it forms the foundation of civilized society; without it, serious abuse of people is more likely to occur. ${ }^{2}$ Human dignity speaks more widely to the moral scope and moral orientation of law. The concept of human dignity has consequences for legislation and for law as a set of norms- particularly, but not exclusively, in defense of human rights, and when used in legal contexts is not to be thought of as a norm, but as a systemic orientation to that conception of the human. ${ }^{3}$

Dignity in international law constitutes an interpretive criterion in favor of broader human rights. Despite the lack of a definition in international law, the appeal to the respect for human dignity is a positive strategy for the defense of human rights. ${ }^{4}$ Nevertheless, according to scholars', definitions are generalizations that try to gather the properties that several entities have in common; but they are unable to cover what is unique or irreplaceable. This is one of the key ideas that the notion of dignity tries to express. It refers, not to a general and abstract human individual, but to thisconcrete-human being who is in front of us. ${ }^{5}$

The use of human dignity has not given rise to a detailed universal interpretation, nor even particularly coherent national interpretations. However, that does not mean that dignity has no role to play in the interpretation of human rights. The absence of a consensus substantive meaning has not prevented it from being used to enable a much looser coordination of human rights adjudication to take place, with significant room for disagreement and divergence over specific practical applications. In this context, a minimum content of the meaning of human dignity can be discerned: each human being possesses an intrinsic worth to be respected, that some forms of conduct are inconsistent with respect for this intrinsic worth, and that the state exists for the individual not vice versa. ${ }^{6}$

\footnotetext{
${ }^{2}$ Michael L., Defining dignity and its place in human rights, 20 New Bioethics 2014, p. 12-34.

${ }^{3}$ Riley S., Human Dignity and the Rule of Law, 11 Utrecht Law Review 2015, pp. 91-105, at p. 105.

${ }^{4}$ Monsalve Bohórquez V. \& Román Aguirre J, Tensions of human dignity: conceptualization and application to international human rights law, 6 Sur. Revista Internacional de Direitos Humanos 2009, available at http://www.scielo.br/scielo.php?pid=S1806$64452009000200003 \&$ script=sci_arttext\&tlng=en (last visited 14 November 2017).

${ }^{5}$ Adorno R., Four paradoxes of human dignity, in Joerden J. et als (eds.), Menschenwürde und modern Medizintechnik, Series: Interdisziplinäre Studien zu Recht und Staat, $\mathrm{n}^{\circ}$ 50, Nomos Verlag, 2011, pp. 131-140, at p. 138.
}

${ }^{6}$ See McCrudden C., Human Dignity and Judicial Interpretation, 19 European Journal of International Law 2008, p. 655-724. 
Every breach of human dignity not only affects the individual victim, but also society as a whole, by raising the question of how we choose to live and relate to each other. ${ }^{7}$ The question rises whether we opt for an international world of human dignity ${ }^{8}$ with the state having a pivotal role in protecting it. This paper examines human dignity as a legal value in two regimes of international law, in the regime of international biolaw and the regime of the human right to water. The purpose of the analysis is to examine the approach of the international community to the notion of human dignity, as perceived subjectively by each of us, in the sphere of bioethics and the human right to water.

\section{A. Human dignity in bioethics}

Human dignity is a core element and an integral part in international bioethics. ${ }^{9}$ In this part of the paper, human dignity is examined in two biolaw texts, the UNESCO Universal Declaration on Bioethics and Human Rights and the Convention on Human Rights and Biomedicine. Despite the fact that the latter is a regional agreement issued by the Council of Europe, it is very important for international biolaw, since it is the first and only binding legal instrument for the protection of human dignity and human rights in the biomedical field and in medical advance.

1. Human dignity in the UNESCO Universal Declaration on Bioethics and Human Rights

The UNESCO Universal Declaration on Bioethics and Human Rights ${ }^{10}$ constitutes a universal non-binding instrument, which covers a wide range of

\footnotetext{
${ }^{7}$ Dupré C., What does dignity mean in a legal context?, The Guardian, 24 March 2011, available at https://www.theguardian.com/commentisfree/libertycentral/2011/mar/24/dignity-uk-europe-humanrights (last visited 14 November 2017).

${ }^{8}$ McDougal S.M., Perspectives for and International Law of Human Dignity, 53 American Society International Law Proceedings 1959, p. 107-132.

${ }^{9}$ Beyleveld D. \& Brownsword R., Human Dignity in Bioethics and Biolaw, Oxford University Press, 2002.

${ }^{10}$ United Nations Educational, Scientific and Cultural Organization, Universal Declaration on Bioethics and Human Rights, 19 October 2005, available at http://portal.unesco.org/en/ev.phpURL ID $=31058 \&$ URL DO=DO TOPIC\&URL SECTION=201.html (last visited 14 November 2017).
} 
bioethical principles. ${ }^{11}$ Specifically, the principles relating to bioethics include the respect to human dignity as enshrined in article 3 of the Declaration, which is entitled 'human dignity and human rights' and in the first paragraph it states that:

Human dignity, human rights and fundamental freedoms are to be fully respected. ${ }^{12}$

Apart from article 3, paragraph 1 the aims of the Universal Declaration include inter alia the promotion of human dignity and the protection of human rights, as well as the recognition of the importance of scientific freedom within the framework of ethical principles and human dignity. ${ }^{13}$

In the UNESCO Declaration human dignity is not used as a technical term, therefore is neither defined nor delineated. The international legislator refers to 'human dignity' as a notion taken and introduced into the Declaration as perceived in general according to common understanding. Therefore, those implementing the Declaration can interpret the notion of human dignity every time ad hoc, without restrains by a rigid definition but on the basis of a large margin of appreciation. Moreover, the generality in the formulation of the principles can be justified by the need to find a balance between the universalism of some bioethical norms and the respect for cultural diversity. ${ }^{14}$

In the human rights discourse the appeal to human dignity is common and they are interrelated. Respect for human rights is based on the respect of human dignity, establishing the latter as their foundation. In this context, the relationship between human rights and human dignity is more than a philosophical, political, legal or sociological debate. It evolves into the foundations for the societies themselves, providing an anthropocentric and rationale status quo to the world we live in. ${ }^{15}$

\footnotetext{
${ }^{11}$ Langlois A., The UNESCO Universal Declaration on Bioethics and Human Rights: Perspectives from Kenya and South Africa, 16 Health Care Anal 2008, p. 39-51.

${ }^{12}$ Universal Declaration on Bioethics and Human Rights, see above, article 3, para 1.

${ }^{13}$ Universal Declaration on Bioethics and Human Rights, see above, article 2.

${ }^{14}$ Andorno R., Global Bioethics at UNESCO: In Defense of the Universal Declaration on Bioethics and Human Rights, 33 Journal of Medical Ethics 2007, p. 150-154.

${ }^{15}$ Moka-Mubelo W., Human Rights and Human Dignity, 3 Reconciling Law and Morality in Human Rights Discourse. Philosophy and Politics-Critical Explorations, Springer, 2017, pp. 89-125.
} 
As for the relationship between human dignity and bioethics, the UNESCO Universal Declaration illustrates the key role of human dignity. The UNESCO Declaration is lex specialis and it could be regarded as an extension of international human rights law in the field of biomedicine. However, a mere appeal to human dignity does not suffice to promote respect for human beings and that is the reason why human dignity and human rights are combined in the UNESCO Declaration, providing a practical tool for solving bioethical dilemmas. ${ }^{16}$

2. The Convention for the protection of Human Rights and Dignity of the Human Being with regard to the Application of Biology and Medicine: Convention on Human Rights and Biomedicine

The Convention on Human Rights and Biomedicine is the first and only binding legal text that focuses on the protection of the rights of the individuals during biomedical treatment and research. It is a document that provides a general juridical and ethical framework on medicine and scientific investigation. It should be noted that in medical law it is difficult to create a broad and harmonized regulation in the context of such a diversity of legal orders and ethical values. ${ }^{17}$

Despite the fact that it is a regional agreement, it is of outmost global significance, since it aims to safeguard human rights and ensure human dignity. Precisely this is reiterated in the preamble of the Convention, where the importance of the dignity of the human being is underlined, along with the necessity to safeguard human dignity with regard to application of biology and medicine, especially when the risks of the latter's misuse are taken into account. ${ }^{18}$

Article 1 of the Convention stipulates its purpose and object. Specifically, it states that:

\footnotetext{
${ }^{16}$ Adorno R., Human Dignity and Human Rights as a Common Ground for a Global Bioethics, 34 The Journal of Medicine and Philosophy: A Forum for Bioethics and Philosophy of Medicine 2009, p. 223240.

${ }^{17}$ Raposo V.L., The Convention of Human Rights and Biomedicine Revisited: Critical Assessment, 20 The International Journal of Human Rights 2016, p. 1277-1294.

${ }^{18}$ Council of Europe, Convention for the Protection of Human Rights and Dignity of the Human Being with regard to the Application of Biology and Medicine: Convention on Human Rights and Biomedicine, Oviedo, 04.04.1997. European Treaty Series - No. 164, Preamble.
} 
Parties to this Convention shall protect the dignity and identity of all human beings and guarantee everyone, without discrimination, respect for their integrity and other rights and fundamental freedoms with regard to the application of biology and medicine. ${ }^{19}$

The aim of first article of the Convention on Human Rights and Biomedicine is the protection of human dignity by the parties with regard to application of biology and medicine; its purpose is to avoid any kind of exploitation of the patient. ${ }^{20}$ The Convention follows a mere anthropocentric approach, according to which humans have a special status in nature, one that can be threatened by the potential of genetic research to reduce individuals to their genetic endowment. ${ }^{21}$

The Convention on Human Rights and Biomedicine is a very important legal tool for the recourse to human dignity. It is noteworthy that its Explanatory Report states that the concept of human dignity constitutes the essential value to be upheld and it is at the basis of most of the values emphasized in the Convention. ${ }^{22}$ Last but not least the title itself of the Convention includes the notion of human dignity.

B. Human dignity in the right to water

This part of the paper examines the notion of human dignity in the contexualization of the human right to water in international law. Yet again, human dignity appears as core element and an integral part of human rights in general and in particular of the right to water. The analysis concentrates on the non-binding instruments of international law on the right to water, such as General Comment No 15 , illustrating the relationship between the latter and human dignity.

\footnotetext{
${ }^{19}$ Convention on Human Rights and Biomedicine, see above, article 1.

${ }^{20}$ Falletti E. \& Cattaneo C., Medical Treatment and Expression of the Consent of the Elderly not able to consent: A Comparative Analysis of the Case Law in the Countries of the Council of Europe, available at http://www.europeanrights.eu/public/commenti/Elderly_people_consent_FALLETTI_blue_book.pdf (last visited 14 November 2017), p. 3.

${ }^{21}$ Chan D.K., The Concept of Human Dignity in the Ethics of Genetic Research, 29 Bioethics 2015, p. 274-282. See also Beyleveld D. \& Brownsword R., Human Dignity, Human Rights and Human Genetics, 61 Modern Law Review 1998, p. 661-680.

${ }^{22}$ Council of Europe, Explanatory Report to the Convention for the protection of Human Rights and Dignity of the Human Being with regard to the Application of Biology and Medicine: Convention on Human Rights and Biomedicine, Oviedo, 04.04.1997. European Treaty Series - No. 164, paragraph 9.
} 
1. Human dignity in General Comment No. 15

General Comment No. 15 on the right to water was adopted by the United Nations Committee on Economic, Social and Cultural Rights and it states that the human right to water is indispensable for leading a life in dignity, as well as a prerequisite for the realization of all human rights. General Comment No. 15 also declares that the right should also be seen in conjunction with other rights, such as the right to life and human dignity. ${ }^{23}$ Despite the fact that it lacks binding force,${ }^{24}$ General Comment No. 15 is very important for the international community, since it is the first legal text that stipulates the human right to water in a global dimension. It obliges all state parties to the International Covenant on Economic, Social and Cultural Rights, delineating their obligations and interpreting the provisions of the Covenant. ${ }^{25}$

Moreover, its significance lies in terms of the inclusion of the notion of human dignity. Specifically, according to the wording of General Comment No. 15 not only the then 'new' human right to water is linked with human dignity but also the latter emerges as a human right itself. ${ }^{26}$ Therefore, the international community introduced two 'new' human rights, the right to water and the right to human dignity. General Comment No. 15 is a substantive normative tool of the International Covenant on Economic, Social and Cultural Rights, which contributes to the progressive development of international $\operatorname{law}^{27}$ and as such it contributes to the global acceptance and recognition of new rights, such as the right to water and human dignity, which are not included in the Covenant. $^{28}$

\footnotetext{
${ }^{23}$ Committee on Economic Social and Cultural Rights, General Comment No. 15, The Right to Water. 20 January 2003 (E/C.12.2002/11).

${ }^{24}$ Chinkin C.M., The Challenge of Soft Law: Development and Change in International Law, 38 International and Comparative Law Quarterly 1989, p. 850-866.

${ }^{25}$ Steiner H.J., Individual Claims in a World of Massive Violence: What Role for the Human Rights Committee?, in Alston Ph. et al. (eds), The Future of UN Human Rights Treaty Monitoring, Cambridge University Press, p. 21.

${ }^{26}$ General Comment No. 15 , see above, para 3.

${ }^{27}$ De Casadevante Romani C.F., Sovereignty and Interpretation of International Norms, Springer, 2007, p. 23.

${ }^{28}$ Boyle A., Some Reflections on the Relationship of Treaties and Soft Law, in Gowlland-Debbas V. et al. (eds), Multilateral Treaty Making, Martinus Nijhoff Publishers, 2000, pp. 25-40, at p. 38.
} 
General Comment No. 15 sets out the nature of the State Parties' obligations inherent in the Covenant by virtue of the right to water. ${ }^{29}$ Certain factors are determined for the adequacy of the right to water, such as the state obligation to respect, protect and fulfill the right to water and sanitation, the provision of sufficient water in good quality, the accessibility and affordability of water, non discrimination for the access to water and the participatory approach in decision making. ${ }^{30}$ The fulfillment of these factors reflects the adequacy of water and thus, the protection of human dignity and life.

General Comment No. 15 constitutes a complete legal text, which provides for the human right to water for everyone and it regulates sufficiently the obligations of the states for the realization of this right. The inclusion of human dignity in the core of the right to water, its connection with it and finally, its emergence as a human right per se indicate that the State Parties to the Covenant appear committed to evolve human dignity from a simple notion to a norm of international law. This assumption along with its interpretative implications highlight the meaning of human dignity when formulating the right of people's to water, in other words the right of everyone to an indispensable good.

2. Recent developments in the relationship between human dignity and the right to water.

The human right to water is explicitly recognized as a right to safe and clean drinking water and sanitation by the United Nations General Assembly Resolution 64/292. The General Assembly calls upon states and international organizations to provide resources and cooperation in order to scale up their efforts for safe, clean, accessible and affordable drinking water and sanitation for all. Once again, in an international soft law text, the right to water and sanitation is stipulated as essential

\footnotetext{
${ }^{29}$ McIntyre O., The UNECE Water Convention and the Human Right to Access to Water: The Protocol on Water and Health, in Tanzi A. et al. (eds), The UNECE Convention on Protection and Use of Transboundary Watercourses and International Lakes. Its Contribution to International Cooperation, Brill Nijhoff, 2015, pp. 345-366, at p. 361.

${ }^{30}$ General Comment No. 15, see above, para 12.
} 
for the full enjoyment of life and all human rights. ${ }^{31}$

In contrast with General Comment No. 15, which stems from a Committee for specific human rights, this resolution goes one step forward and states that the official recognition of the human right to water is an international community issue. The United Nations Resolution contextualizes a human right which was, until then, selfevident, yet not incorporated into law. The right to water reflects the indivisibility of human rights, since it constitutes a precondition for the realization of other rights, such as the rights to life and health. ${ }^{32}$

However, it is noteworthy that the notion of human dignity in this contextualization of the right to water is absent and there is no reference in the United Nations Resolution to the fundamental link between human dignity and the right to water. As if the absence of such a reference was recognized by the international legislator, in 2011 the Human Rights Council through its Resolution 16/2 on the human right to safe drinking water and sanitation amends the aforementioned omission.

The first paragraph of the Resolution 16/2 states that:

[...] the human right to safe drinking water and sanitation is derived from the right to an adequate standard of living and inextricably related to the right to the highest attainable standard of physical and mental health, as well as the right to life and human dignity. ${ }^{33}$

Moreover, in 2015 the General Assembly in its Resolution 70/169 on the human rights to safe drinking water and sanitation, establishes the access to sanitation as a human right. Specifically, it recognizes that the right to sanitation entitles everyone to have physical and affordable access to sanitation, in all spheres of life, that is safe, hygienic, secure, socially and culturally acceptable and that provides privacy and ensures dignity. ${ }^{34}$

The case of sanitation is rather sensitive requiring a special attention, since the

\footnotetext{
${ }^{31}$ United Nations General Assembly Resolution, The Human Right to Water and Sanitation. 28 July 2010 (A/RES/64/292).

${ }^{32}$ Tzatzaki V., National Approaches for the Realization of a Human Right to Water, in Lohse E. et al. (eds), Best Practices for the Protection of Water by Law, Berliner Wissenschafts-Verlag, 2017, pp.1329 , at p. 15 .

${ }^{33}$ Human Rights Council Resolution, The Human Right to Safe Drinking Water and Sanitation. 08 April 2011 (A/HRC/RES/16/2), para 1.

${ }^{34}$ United Nations General Assembly Resolution, The Human Rights to Safe Drinking Water and Sanitation. 22 February 2016 (A/RES/70/169), para 2.
} 
human right to sanitation actually gives to everybody the right to have access to such services, which must be secure, hygienic, affordable and that provide privacy and ensure dignity. Privacy and dignity are related to people's social and cultural standards and take into consideration gender-related particularities, such as the use conditions of women and young girls. In other words, it could be argued that dignity and privacy evolve into human rights principles that permeate international human rights law and are relevant to the human right to sanitation and associated hygiene. ${ }^{35}$

The same year countries set a nexus of goals, in order to eradicate poverty and ensure prosperity for everyone. These are the sustainable development goals and each of them has specific targets to be achieved over the next 15 years, demanding the cooperation between governments, the private sector and the civil society. Goal 6 refers to the importance of ensuring access to water and sanitation for all, highlighting the challenges and the problems that the global society faces nowadays in regards to the quality and quantity of fresh water.

In the wording as well as in the description of the justification of Goal 6 there is no explicit reference to human dignity. Instead there is reference to the negative impacts of water scarcity, poor water quality and inadequate sanitation on food security, livelihood choices and educational opportunities for poor families across the world. Drought afflicts some of the world's poorest countries, worsening hunger and malnutrition. ${ }^{36}$ The depiction of the above actually corresponds to situations where human dignity is blatantly attacked and insulted. The absence of the words 'human dignity' is substituted by a vivid description of a status quo that human existence is devaluated and apart from the right to water, a number of other rights, such as the right to education, to food, to security are also violated.

\section{Conclusion}

Human dignity and human rights are interrelated; they go hand in hand and the

\footnotetext{
${ }^{35}$ See de Albuquerque C., Realising the Human Rights to Water and Sanitation: A Handbook by the UN Special Rapporteur Catarina de Albuquerque, 2014, available at http://www.ohchr.org/EN/Issues/WaterAndSanitation/SRWater/Pages/Handbook.aspx (last visited 14 November 2017).

${ }^{36}$ Sustainable Development Goals, 25 September 2015, available at http://www.un.org/sustainabledevelopment/water-and-sanitation/ (last visited 14 November 2017).
} 
protection of human dignity safeguards the protection of human rights and vice versa. In international human rights law the notion of dignity is a protagonist not only in legal texts but also in their practical implementation. The present paper examined the role of human dignity in two regimes of international law, biolaw and the human right to water, the first as a regime which regulates the use of science and medicine with respect to the rights of individuals and the second as a regime for the preservation of the most indispensable good for human nature.

In international biolaw human dignity is reiterated in the UNESCO Universal Declaration on Bioethics and Human Rights, as well as in the Convention on Human Rights and Biomedicine. These two legal instruments incorporate the notion of human dignity in an ever developing field of science and law, biomedicine, as a basis for the protection of the individual and its rights. The notion is repeated several times in the texts exhibiting not only its importance but its profound connection with the aims of the Declaration and the Convention, namely the protection of human rights in the application of biology and medicine.

On the other hand, in the international legal documents for the establishment and protection of the human right to water, human dignity also appears as a core element. The indivisibility of dignity and the human right to water is expanded in other human rights, such as the right to life and health. People have the right to be treated with dignity, regardless of their nationality, religion, color, sex language or any other possible basis for discrimination. All human rights are not only interrelated to each other but also interdependent with the notion of dignity.

According to the aforementioned, human dignity as it appears in international biolaw and in the human right to water is a prevailing notion, indispensable for the protection of the rights of the individual. The absence of a concrete definition does not at all imply that it lacks substance; on the contrary, the international legislator opted for flexibility and adjustability to each case, thus offering a huge vast of application and interpretation of the notion.

The systemic inclusion of human dignity in the legal instruments by the international community illustrates the recognition of its importance and its significance for the protection of human rights. Human dignity, regardless of a 
definition or a place in the hierarchy of international rules and principles, emerges as the bond between all human rights, as the indispensable link for the respect of the individuals. Therefore, in the international legal nexus of human rights, dignity is the starting point for their protection, taking into account the very nature of human beings along with their needs.

Bibliography:

1. Adorno R., Four Paradoxes of Human Dignity, in Joerden J. et als (eds.), Menschenwürde und modern Medizintechnik, Series: Interdisziplinäre Studien zu Recht und Staat, $\mathrm{n}^{\circ}$ 50, Nomos Verlag, 2011, pp. 131-140.

2. Adorno R., Human Dignity and Human Rights as a Common Ground for a Global Bioethics, 34 The Journal of Medicine and Philosophy: A Forum for Bioethics and Philosophy of Medicine 2009, p. 223-240.

3. Andorno R., Global bioethics at UNESCO: In Defense of the Universal Declaration on Bioethics and Human Rights, 33 Journal of Medical Ethics 2007, p. 150-154.

4. Beyleveld D. \& Brownsword R., Human Dignity in Bioethics and Biolaw, Oxford University Press, 2002.

5. Beyleveld D. \& Brownsword R., Human Dignity, Human Rights and Human Genetics, 61 Modern Law Review 1998, p. 661-680.

6. Boyle A., Some Reflections on the Relationship of Treaties and Soft Law, in Gowlland-Debbas V. et al. (eds), Multilateral Treaty Making, Martinus Nijhoff Publishers, 2000, pp. 25-40.

7. Chan D.K., The Concept of Human Dignity in the Ethics of Genetic Research, 29 Bioethics 2015, p. 274-282.

8. Chinkin C.M., The Challenge of Soft Law: Development and Change in International Law, 38 International and Comparative Law Quarterly 1989, p. 850-866.

9. Committee on Economic Social and Cultural Rights, General Comment No. 15, The Right to Water. 20 January 2003 (E/C.12.2002/11).

10. Council of Europe, Convention for the Protection of Human Rights and Dignity of the Human Being with regard to the Application of Biology and Medicine: Convention on Human Rights and Biomedicine, Oviedo, 04.04.1997. European Treaty Series - No. 164.

11. Council of Europe, Explanatory Report to the Convention for the Protection of Human Rights and Dignity of the Human Being with regard to the Application of Biology and Medicine: Convention on Human Rights and Biomedicine, Oviedo, 04.04.1997. European Treaty Series - No. 164.

12. De Albuquerque C., Realising the Human Rights to Water and Sanitation: A Handbook by the UN Special Rapporteur Catarina de Albuquerque, 2014, available at http://www.ohchr.org/EN/Issues/WaterAndSanitation/SRWater/Pages/Handbook.asp $\underline{x}$ (last visited 14 November 2017).

13. De Casadevante Romani C.F., Sovereignty and Interpretation of International Norms, Springer, 2007.

14. Dupré C., What does Dignity Mean in a Legal Context?, The Guardian, 24 March 2011, available https://www.theguardian.com/commentisfree/libertycentral/2011/mar/24/dignity-ukeurope-human-rights (last visited 14 November 2017).

15. Falletti E. \& Cattaneo C., Medical Treatment and Expression of the Consent of the Elderly not able to consent: A Comparative Analysis of the Case Law in the Countries of the Council of Europe, available at 
http://www.europeanrights.eu/public/commenti/Elderly_people_consent_FALLETTI blue_book.pdf (last visited 14 November 2017).

16. Human Rights Council Resolution, The Human Right to Safe Drinking Water and Sanitation. 08 April 2011 (A/HRC/RES/16/2).

17. Jackson V., Constitutional Dialogue and Human Dignity: States and Transnational Constitutional Discourse, 65 Montana Law Review 2004, pp. 15-40.

18. Langlois A., The UNESCO Universal Declaration on Bioethics and Human Rights: Perspectives from Kenya and South Africa, 16 Health Care Anal 2008, p. 39-51.

19. McCrudden C., Human Dignity and Judicial Interpretation, 19 European Journal of International Law 2008, p. 655-724.

20. McDougal S.M., Perspectives for and International Law of Human Dignity, 53 American Society International Law Proceedings 1959, p. 107-132.

21. McIntyre O., The UNECE Water Convention and the Human Right to Access to Water: The Protocol on Water and Health, in Tanzi A. et al. (eds), The UNECE Convention on Protection and Use of Transboundary Watercourses and International Lakes. Its Contribution to International Cooperation, Brill Nijhoff, 2015, pp. 345-366.

22. Michael L., Defining Dignity and its Place in Human Rights, 20 New Bioethics 2014, p. 12-34.

23. Moka-Mubelo W., Human Rights and Human Dignity, 3 Reconciling Law and Morality in Human Rights Discourse. Philosophy and Politics-Critical Explorations, Springer, 2017.

24. Monsalve Bohórquez V. \& Román Aguirre J, Tensions of Human Dignity: Conceptualization and Application to International Human Rights Law, 6 Sur. Revista Internacional de Direitos Humanos 2009, available at http://www.scielo.br/scielo.php?pid=S180664452009000200003\&script=sci_arttext\&tlng=en (last visited 14 November 2017).

25. See also Rao N., Three Concepts of Dignity in Constitutional Law, 86 Notre Dame Law Review 2011, p. 813-272.

26. Raposo V.L., The Convention of Human Rights and Biomedicine Revisited: Critical Assessment, 20 The International Journal of Human Rights 2016, p. 1277-1294.

27. Riley S., Human Dignity and the Rule of Law, 11 Utrecht Law Review 2015, pp. 91105.

28. Steiner H.J., Individual Claims in a World of Massive Violence: What Role for the Human Rights Committee?, in Alston Ph. et al. (eds), The Future of UN Human Rights Treaty Monitoring, Cambridge University Press.

29. Sustainable Development Goals, 25 September 2015, available at http://www.un.org/sustainabledevelopment/water-and-sanitation/.

30. Tzatzaki V., National Approaches for the Realization of a Human Right to Water, in Lohse E. et al. (eds), Best Practices for the Protection of Water by Law, Berliner Wissenschafts-Verlag, 2017, pp.13-29.

31. United Nations Educational, Scientific and Cultural Organization, Universal Declaration on Bioethics and Human Rights, 19 October 2005, available at http://portal.unesco.org/en/ev.phpURL_ID=31058\&URL_DO=DO_TOPIC\&URL_SECTION=201.html (last visited 14 November 2017).

32. United Nations General Assembly Resolution, The Human Right to Water and Sanitation. 28 July 2010 (A/RES/64/292).

33. United Nations General Assembly Resolution, The Human Rights to Safe Drinking Water and Sanitation. 22 February 2016 (A/RES/70/169). 